\title{
4 \\ Hydraulic Assessment of the Ganaraska River, Port Hope, Ontario
}

\section{Peter Nimmrichter}

The existing hydrologic model of the Ganaraska River Watershed, developed about twenty years ago, and the Regulatory Flood, estimated using that model, was not considered reflective of current watershed conditions by the Ganaraska River Conservation Authority (GRCA). Also, the Cameco Corporation property near the mouth of the Ganaraska River is potentially affected by the Regulatory Flood limit and the Corporation, therefore, had an interest in accurately defining the Regulatory Flood limit.

The GRCA and Cameco agreed to address the necessary technical update with two studies - a hydrology study prepared by the GRCA with the assistance of Schaeffers Consulting Engineers and a hydraulics study prepared by Cameco Corporation with the assistance of AMEC.

The peak flow estimates computed with the newly developed hydrologic model, a component deliverable of the recently completed hydrology study, changed from those previously generated using the 1980's vintage simulation model. Therefore, there was a need to update the present Regulatory Flood Plain delineation and mapping to reflect the new flood flow estimates.

The objective of this study was to undertake a hydraulic assessment of the Ganaraska River from the mouth of the river at Lake Ontario to the Robertson Street Bridge, as illustrated in Figure 4.1, and to compute the water levels for the purposes of identifying flood proofing elevations for the Cameco site.

Nimmrichter, P. 2008. "Hydraulic Assessment of the Ganaraska River, Port Hope, Ontario." Journal of Water Management Modeling R228-04. doi: 10.14796/JWMM.R228-04.

(C) CHI 2008 www.chijournal.org ISSN: 2292-6062 (Formerly in Reliable Modeling of Urban Water Systems. ISBN: 978-0-9808853-0-9) 


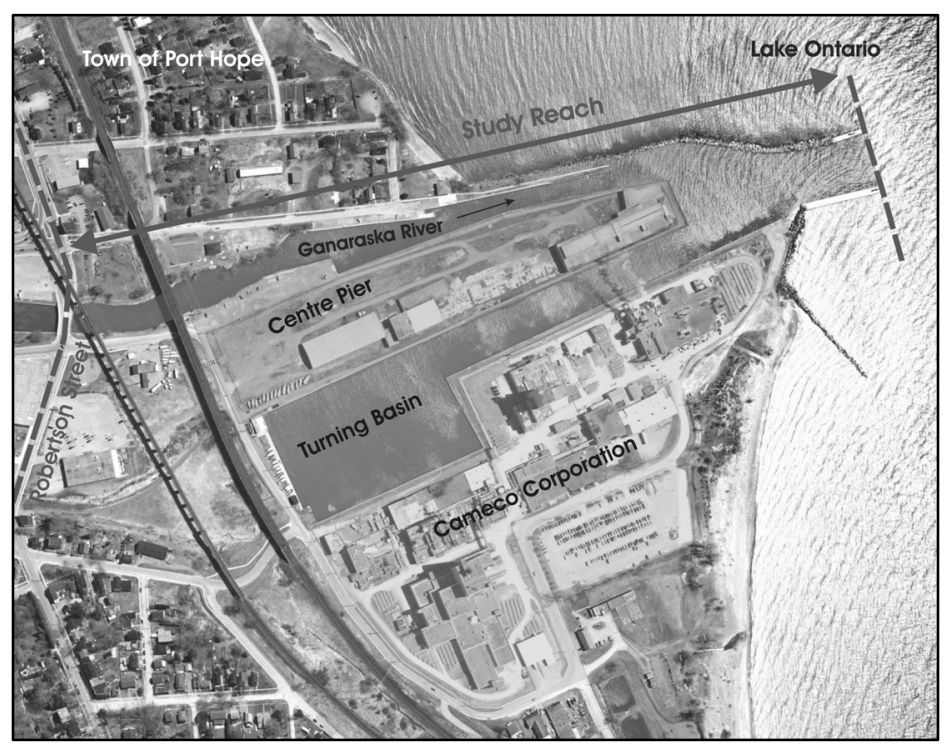

Figure 4.1 Study area.

\subsection{Background Data Review}

A number of previous flood related documents and data were reviewed for this study. This data also included a photographic database of ice data.

The GRCA's photographic history of ice conditions in the Ganaraska River (from 1986 to 1993) and additional photos provided by local citizens were used as the basis for characterization of the nature of ice accumulation along the subject reach. The review of approximately 5000 photographs and discussions with GRCA staff identified three locations in the study reach with historic ice cover (see Figure 4.2), namely:

Location 1: From upstream of the Robertson Street Bridge to below the CNR viaduct.

Location 2: From the northern end of the first building on the Centre Pier to the start of the eastern breakwater.

Location 3: From just north of the Ganaraska River / Turning Basin / approach channel confluence to the harbour mouth. 


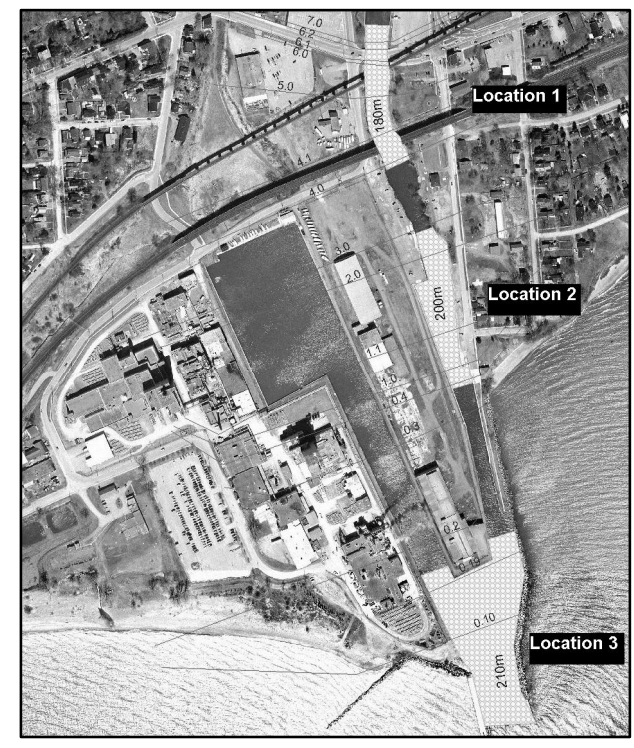

Figure 4.2 Areas prone to ice accumulation.

The only quantitative ice data, available to this project, was gathered for the period January 1981 to March 20, 1981 and documented in Ganaraska River Ice Data in the Town of Port Hope (TSH, 1981c). This report documented that, along the study reach, the maximum ice thickness was $2.1 \mathrm{ft}(0.64 \mathrm{~m})$, however this did not occur across the entire channel or over the entire reach. No flow velocity data was documented in this report.

Flood flow data were provided by the GRCA (see Table 4.1).

No streamflow gauges exist along the subject reach of the Ganaraska River. The only known flood event for which a flood inundation limit has been defined is the flood of 1980 (TSH, 1981a).

The cause of the spring 1980 flood is documented as a rain event falling onto frozen ground (TSH, 1981a). GRCA staff indicated that the rainfall was estimated as a 1 in $5 \mathrm{y}$ event and the resultant flow the 1 in $100 \mathrm{y}$ flood. The available photographs also suggest that ice blockage of the river channel was a contributing factor to flooding during this event, particularly in the lower reaches of the River.

The basis for the Regulatory Flood is Hurricane Hazel, a summer time thunderstorm event. The $100 \mathrm{y}$ flood limits are also based on a summer time 
event. As such, the parameterization of the hydraulic model was to be consistent with a summer timeframe.

No other data was available to support a calibration / validation effort for this reach of the Ganaraska River.

Table 4.1 GRCA flood flows.

\begin{tabular}{lc}
\hline Event & Flow $\left(\mathrm{m}^{3} / \mathrm{s}\right)$ \\
\hline 100 Year Flood & 425 \\
Regional Flood & 748 \\
Probable Maximum Flood & 1454 \\
\hline
\end{tabular}

\subsection{Flood Plain Calculations}

\subsubsection{Overview}

The Centre Pier area acts as the west bank of the Ganaraska River at low flow. As flow in the river increases, rising water levels will eventually overtop the Centre Pier and flow will "split", some continuing to Lake Ontario via the Ganaraska River and some will flow into the Turning Basin, which lies between the Centre Pier and the Cameco Corporation property. Recent flood plain analyses undertaken on behalf of Cameco Corporation by Totten Sims Hubicki (TSH) completed a simplified assessment of this split flow condition using HEC-2. Given the hydraulic complexities of the waterfront area near the mouth of the Ganaraska River, a more detailed assessment of this condition using a two-dimensional hydraulic modeling approach was a requirement of this project. The two-dimensional hydraulic modeling program selected for this project component was TASE/SWAN (TASE, 1994).

The Terms of Reference further identified the HEC-RAS (1-D) hydraulic model, developed by the U.S. Army Corps of Engineers, for computation of water surface elevations for flood plain mapping purposes for this project. As such, the results of the two-dimensional flow assessment were integrated into the general hydraulic model (i.e. HEC-RAS) of the Ganaraska River, through a calibration effort, to establish the Regulatory Flood Plain along the subject reach. 


\subsubsection{Base Model Conditions}

The following elements of the hydraulic model were determined through discussion with the Project Steering Committee.

- Proposals affecting the study area in various stages of development were identified, but integration of any of these proposals into the hydraulic evaluation for the purposes of defining the Regulatory flood plain would be presumptive and speculative. The base condition to be modeled for the purposes of preparing the updated Regulatory Flood Plain map was existing conditions as of today as reflected by the available mapping base. This approach is consistent with Ontario Ministry of Natural Resources (OMNR) Flood Plain Management Technical Guidelines (OMNR, 1988a) and supported by GRCA staff.

- The Lake Ontario water surface elevation to be used as the boundary condition for the purposes of hydraulic modeling for the Regulatory Flood will be the mean annual lake elevation of $74.7 \mathrm{~m}(245.09 \mathrm{ft})$. This is consistent with the OMNR Flood Plain Management Technical Guidelines (OMNR, 1988a).

- The hydraulic roughness coefficients (Manning's ' $n$ ') and expansion/contraction coefficients to be used will be developed in compliance with the Ganaraska Region Conservation Authority (GRCA) Flood Plain Mapping standards.

- The river bed elevations in the Ganaraska River will be defined as per the TSH 2004 hydraulic models. A review of the TSH model revealed that a conservative approach was utilized assuming dredging to $8 \mathrm{ft} / 2.4 \mathrm{~m}$ (below the mean lake level) and $2 \mathrm{ft} / 0.6 \mathrm{~m}$ of siltation resulting in a maximum river depth of $6 \mathrm{ft} / 1.8 \mathrm{~m}$.

- The breakwater on the east side, near the mouth of the river was conservatively modeled as a solid object in the hydraulic simulation model even though visual inspection of the breakwater clearly indicates that it is not an impervious wall. 


\subsubsection{Flood Flows}

As stated in the Flood Plain Management in Ontario, Technical Guidelines (OMNR, 1988a):

The Regulatory Floods selected for the Province are designed to accomplish the main objectives of flood plain management, to prevent loss of life and to minimize property damage and social disruption. The Regulatory Flood is the basis of which flood plains are delineated.

The Ganaraska River Watershed lies within Zone 1, as defined by the OMNR guidelines (OMNR, 1988a and OMNR, 1988b), and as such the Regulatory Flood is defined by the greater of (OMNR, 1988a):

- the flood level corresponding to the peak flow generated by the Regional Storm (Hurricane Hazel),

- an observed and well documented flood level,

- the 100-y flood level.

As noted previously, all flood flow estimates used for this hydraulic evaluation were provided by the GRCA. Based on the above guideline, the following comparison can be made:

- Referencing Table 4.1, the Regional Flood is estimated as $748 \mathrm{~m}^{3} / \mathrm{s}$.

- A review of the 1980 flood event concluded that the limits of flooding were well within those estimated for the Regulatory Flood (TSH, 1981a). The Regulatory Flood was estimated at the time as about $790 \mathrm{~m}^{3} / \mathrm{s}$ (TSH, 1981b).

- The $100 \mathrm{y}$ flood flow is estimated as $425 \mathrm{~m}^{3} / \mathrm{s}$.

Therefore, in the case of the Ganaraska River, the Regulatory Flood was defined using a Hurricane Hazel (Regional Storm) based event.

The GRCA stipulated that a quantitative assessment of the 1980 flood beyond that provided in the Ganaraska River Flood Control Study, (TSH, 1981a) was required in the context of establishing the Regulatory Floodplain in compliance with MNR guidelines. As such, modeling of ice cover representative of the 1980 event within the study reach was required for comparative evaluation of flood conditions resulting from the Regulatory Flood.

\subsubsection{Topographic Mapping}

The mapping base for this project included 1:2000 OBM and 2001 detailed site survey of the Cameco Corporation property. The Digital Terrain Model 
(DTM) of the study area for use on this project was developed from this topographic mapping base.

\subsubsection{Two Dimensional Modeling}

\section{TASE/SWAN Program}

TASE/SWAN is a general purpose numerical package for the hydrodynamic simulation of the flow field and constituent transport in a two-dimensional (in plan) water body under steady and unsteady conditions. The numerical method for solving the two-dimensional St.-Venant shallow water wave equations is based on a finite volume technique. TASE/SWAN has no Froude number restrictions and can compute across flows that switch between sub-critical and super-critical.

The TASE/SWAN computing domain is defined by the user as zones in an $x-y$ region, within which the model generates a computational mesh. Ground levels, or bathymetry, may be entered as contours from which TASE/SWAN interpolates the level of each mesh cell. Manning's roughness coefficients and starting water levels may be specified by zone or individual mesh cell. (TASE, 1994)

In addition to the evaluation completed for the Ganaraska River, AMEC has successfully used the TASE/SWAN software on a variety of dam safety projects for a number of clients including INCO, Great Lakes Power and Ontario Power Generation.

\section{Study Reach TASE/SWAN Model}

The 2-D model was constructed by creating zones representing different land use features, such as the Ganaraska River, the Turning Basin, the Centre Pier, Cameco's property, etc. The boundaries of these zones can be defined by the model limits, river banks, the lake shore, the Turning Basin, etc. Once the zones had been defined the model generates an orthogonal mesh within each zone to provide a detailed representation of elevation variations within the zone. The bathymetry and ground elevations within the model are then generated from the digital mapping base described above. Finally, the Manning's ' $n$ ' roughness coefficients were assigned to each zone. Figure 4.3 illustrates the base model for the study reach.

The next step was to enhance the base model by incorporating flood plain features and other conditions, including: 
- Defining buildings within the flood plain by changing the ground elevations of the occupied cells to the building's roof elevation.

- The northern boundary of the model between the abutments of the CNR viaduct was defined as the inflow boundary.

- The shoreline of Lake Ontario and mouth of the Ganaraska River were set to the mean annual lake level for Lake Ontario.

- Adjusting the bed elevation near the mouth of the river and Turning Basin approach channel to the normal dredged elevation.

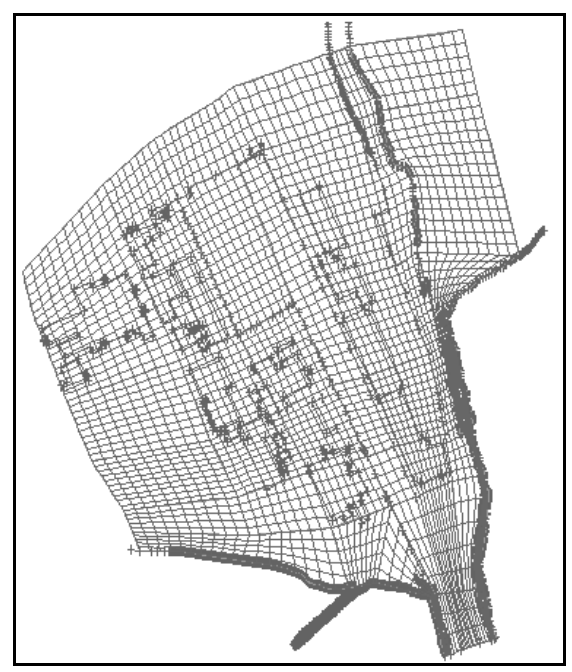

Figure 4.3 TASE/SWAN 2D base model.

\section{Two Dimensional Modeling Results}

The 2-D hydraulic model was used to better simulate the hydraulic complexities of the waterfront area near the mouth of the Ganaraska River and due to uncertainties regarding the "splitting" of flow east and west of the Centre Pier at high flows. The traditional flood plain simulation programs HEC-2 and HEC-RAS are 1-D hydraulic models which assume all flow moves in singular direction, clearly not the case for this study reach. 
Figure 4.4 illustrates Regulatory Flood flow depths and velocity vectors for the base 2D model. The results indicated that the buildings and soil pile on the Centre Pier act to contain flow in the main Ganaraska River channel under high flow conditions. The main channel also experiences higher flow velocities (up to $4.0 \mathrm{~m} / \mathrm{s}$ ) than those in the Turning Basin (up to $1.0 \mathrm{~m} / \mathrm{s}$ ). Flood depths in the study reach range up to $2 \mathrm{~m}$ in the areas of the Centre Pier and to the east of the main Ganaraska River channel.

The TASE/SWAN results indicated that about $125 \mathrm{~m}^{3} / \mathrm{s}$ of the Regulatory Flood peak (about 20\%) "splits" into the Turning Basin. By comparison, the HEC-2 model (TSH, 2004) computed about $240 \mathrm{~m}^{3} / \mathrm{s}$ of the Regulatory Flood peak of $717 \mathrm{~m}^{3} / \mathrm{s}$ (about 33\%) is diverted. The difference between the HEC-2 and the 2D hydraulic model computations was the result of lower computed water levels and differences in modeled topography in the location of the HEC-2 weir and that modeled in the 2-D model.

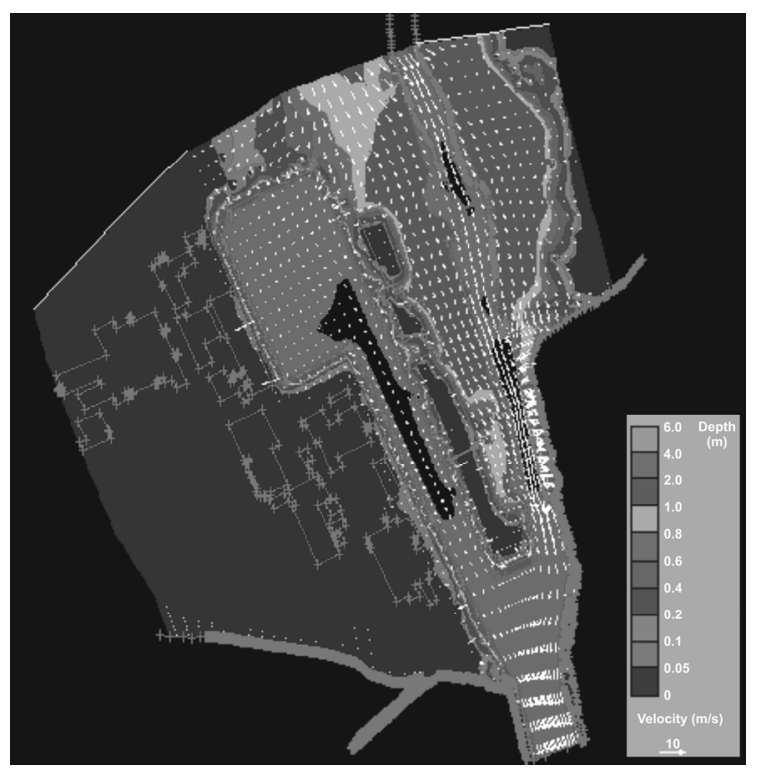

Figure 4.4 TASE/SWAN 2-D Model computations for the regulatory flood under existing conditions.

Greenland International Consulting, in their capacity as the GRCA's peer reviewer, recommended that any future grading or structural alterations along the Centre Pier and up to Hayward Street should first be modeled and 
approved by the GRCA to ensure no change in water surface elevations as this could potentially increase the flooding adjacent the Cameco site.

\subsubsection{Steady State (One Dimensional) Modeling}

\section{HEC-RAS Program}

HEC-RAS is an approved model for flood plain calculations in Ontario and identified as the required modeling platform in the Terms of Reference for this project. In HEC-RAS (1-D) models, flood levels are based on representative cross-sections and cross-section averaged flow characteristics. Typically, water surface levels and flow velocities vary across a flood plain. A 1-D steady state model cannot resolve these variations resulting in more conservative estimates of inundated floodplain areas, compared with unsteady state models or 2-D models, because steady flow models do not consider the effects of time and the resultant change in the rate of water storage (ADWR, 2002, TetraTech, 2004).

HEC-GeoRAS is a pre- and post-processing program developed cooperatively by the Hydrologic Engineering Center (HEC) of the US Army Corps of Engineers and the Environmental Systems Research Institute Inc. (ESRI). The HEC-GeoRAS 3.1.1 extension to ArcView 3.2 and HEC-RAS 3.1.3 were used to complete the one dimensional hydraulic modeling component of this project.

\section{HEC-RAS Model of the Study Reach}

The starting point for development of the HEC-RAS model of the study reach was the HEC-2 model of the same reach of the river developed by TSH (TSH, 2004). A number of new sections were added to facilitate enhancement of the original HEC-2 model. Additional enhancements included setting the starting water surface elevation to the mean annual lake level of $74.7 \mathrm{~m}$, extending the model to the present mouth of the Ganaraska River and the main channel and Turning Basin were modeled in a single dataset using a looped network configuration.

\section{Sensitivity Analysis}

The sensitivity analysis completed for this study focused on four input parameters, namely: Manning's roughness co-efficient, flood flow, lateral weir co-efficient, and expansion/contraction co-efficients $( \pm 20 \%)$. The results indicate that computed water levels in both the Turning Basin and the 
main river channel are sensitive only to changes in flood flows (of the parameters evaluated).

\section{HEC-RAS Modeling Results}

The Terms of Reference required that the results of the two-dimensional flow analyses be integrated into the HEC-RAS hydraulic model through a calibration process to establish the Regulatory Flood Plain. The adjustments to the base hydraulic HEC-RAS model stemming from the calibration process included the following:

- The lateral weir definition representing eastern breakwater was extended through this area to quantify the flow lost from the system in this zone.

- At river section 0.2, the computed water surface elevation drops by more than $1.0 \mathrm{~m}$ compared with the upstream section 0.25 [for the Regulatory Flood]. A review of computations in the area indicated that HEC-RAS calculations were defaulted to critical depth as the energy equation could not be balanced. Further review concluded that adding sections to the model did not resolve the computations and the hydraulic grade line was used to graphical determine sub-critical flow elevations through this reach. The results also suggested the potential for the formation of a hydraulic jump in the downstream area of this reach.

Table 4.2 summarizes the results of the Regulatory Flood computations from the 2-D and HEC-RAS models. Additional changes to reduce the differences between the two models were without an engineering basis and therefore not considered. The results support the expectation of more conservative computations from the HEC-RAS (1-D) steady state hydraulic model when compared with the results from the 2-D hydraulic model.

\section{Ice Modeling}

GRCA staff indicated that a quantitative assessment of the 1980 flood beyond that provided in the Ganaraska River Flood Control Study, (TSH, 1981a) was required in the context of establishing the Regulatory Floodplain in compliance with MNR guidelines. As such, modeling of ice cover within the study reach was required for comparative evaluation of flood conditions resulting from the Regulatory Flood. 
Table 4.2 Summary of Regulatory Flood Plain Calculations TASE/SWAN compared with HEC-RAS

\begin{tabular}{|c|c|c|c|c|c|c|}
\hline \multirow[t]{2}{*}{ Station } & \multicolumn{3}{|c|}{ Turning Basin } & \multicolumn{3}{|c|}{ Ganaraska River } \\
\hline & $\begin{array}{l}\text { Flow } \\
\left(\mathrm{m}^{3} / \mathrm{s}\right)\end{array}$ & $\begin{array}{c}2 \mathrm{D} \\
\text { Model } \\
(\mathrm{m})\end{array}$ & $\begin{array}{c}\text { HEC-RAS } \\
\text { Model } \\
\text { (m) }\end{array}$ & $\begin{array}{l}\text { Flow } \\
\left(\mathrm{m}^{3} / \mathrm{s}\right)\end{array}$ & $\begin{array}{c}\text { 2D } \\
\text { Model } \\
(\mathrm{m})\end{array}$ & $\begin{array}{c}\text { HEC-RAS } \\
\text { Model } \\
\text { (m) }\end{array}$ \\
\hline 6 & & & & 748 & & 78.07 \\
\hline 5 & & & & 748 & & 78.12 \\
\hline 4.1 & & & & 748 & 77.50 & 78.15 \\
\hline 4 & & & & 748 & 77.50 & 78.17 \\
\hline 3 & 125 & 76.10 & 76.12 & 623 & 77.50 & 78.13 \\
\hline 2 & 125 & 76.10 & 76.12 & 623 & 77.50 & 78.09 \\
\hline 1.1 & 125 & 76.10 & 76.12 & 623 & 77.30 & 77.94 \\
\hline 1 & 125 & 76.10 & 76.09 & 623 & 77.20 & 77.96 \\
\hline $0.4 / 0.7^{1}$ & 125 & 76.10 & 76.09 & 623 & 77.20 & 77.90 \\
\hline 0.3 & 125 & 76.10 & 76.09 & 476 & 77.00 & 77.58 \\
\hline 0.25 & 125 & 76.10 & 76.08 & 367 & 77.00 & 77.08 \\
\hline 0.2 & 125 & 76.00 & 76.07 & 319 & 76.50 & 76.40 \\
\hline 0.195 & 125 & 76.00 & 76.05 & 319 & 76.00 & 75.77 \\
\hline 0.1 & & & & 444 & 76.00 & 75.91 \\
\hline 0 & & & & 444 & 74.70 & 74.79 \\
\hline
\end{tabular}

As noted previously, the photographic history of ice conditions in the Ganaraska River were used as the basis for characterization of the nature of ice accumulation and hydraulic model development. Three locations were identified in the study reach with historic ice cover, as illustrated in Figure 4.2. In consultation with GRCA staff, Location 1 was selected for ice cover modeling with the 1980 flood flow for the purposes of evaluating the maximum limit of the Regulatory Floodplain.

Two modeling approaches were used to evaluate water surface elevations associated with ice conditions: the TASE/SWAN 2-D program, and the HEC-RAS program using the ice cover modeling utilities in the program.

Using the TASE/SWAN 2-D program a conservative approach was developed whereby a static ice cover with complete blockage of the river channel to a bank full elevation along the length of the ice cover location was modeled.

Although limited, the data provided by (TSH, 1981c) provided a basis for describing ice thickness over the reach of interest for modeling of ice cover using HEC-RAS. HEC-RAS default values for ice cover roughness were used. An average ice thickness of $0.5 \mathrm{~m}$ was used and $100 \%$ ice cover over Location 1 was assumed. 
The comparative results indicated that the maximum water levels are associated with the Regional Flood. As such, the floodplain mapping was based on the computed water levels associated with the Regulatory Flood.

\subsection{Flood Proofing}

A resolution passed by the GRCA, dated June 18, 2004, requested a review of flooding impacts to the Cameco Corporation property from events greater than the Regional Storm.

Section 3.1.3 of the Provincial Policy Statement indicates that development is not permitted in the flood plain where hazardous substances are involved and that the definition for hazardous substances includes radioactive materials. Further, Sections 8.1 and 8.2 of the 1988 Flood Plain Planning Policy require a higher level of flood proofing (beyond the Regulatory Event) due to the sensitive nature of the development. This is also documented in the Technical Guide for River \& Stream Systems: Flooding Hazard Limit (OMNR, 2002) under Section 2.10 Public Safety.

OMNR recommended that the Probable Maximum Flood (PMF) should be used as the flood proofing standard for the Cameco Corporation, Port Hope situation. The PMF is recognized by the OMNR as the event that is greater than the Regional Storm.

Flood proofing is a process for preventing or reducing flood damages to the structure/site and/or to the contents of buildings/sites located in flood hazard areas. It can be incorporated into the design and construction of new buildings or retrofitted onto existing structures. There are three general approaches to flood proofing:

- raising or moving the structure,

- constructing barriers to stop floodwater from entering the structure/site, and

- wet flood proofing whereby floodwaters are allowed to enter the structure/site, but ensuring that there is no or minimal damage to the building's structure/site and to its contents.

\subsubsection{Study Reach Conditions}

This flood proofing evaluation was based on two scenarios, namely, the Probable Maximum Flood, and, a spring ice/debris jam using the $100 \mathrm{y}$ peak flow. 
All hydraulic modeling requirements, excepting flow and ice/debris jam definitions, were consistent with those used for the hydraulic evaluation of the Regulatory Flood Plain.

The flood peak of the PMF is estimated as $1454 \mathrm{~m}^{3} / \mathrm{s}$ for the study reach of the Ganaraska River (see Table 4.1).

\section{Ice Jams}

The assessment of river blockages focused on winter ice and summer debris scenarios. As the method of assessment was similar for both the winter and summer scenarios it was clear that the winter scenario was the critical of the two. This analysis proceeded, therefore, with a focus on the winter scenario only.

The OMNR Technical Guidelines (OMNR, 1988a) and the New Brunswick River Ice Manual (NBDOE, 1989) provide an overview of ice jam processes and methods for evaluation of water levels associated with ice jams. Both documents indicate that numerical methods for evaluating water levels associated with ice jams are not as refined as those available for open water scenarios and that the data requirements for detailed assessment of river ice jams are significant and includes observations such as flow velocities and ice thickness.

\subsubsection{Flood Proofing Elevations}

Two modeling approaches were used to evaluate water surface elevations associated with ice conditions, namely: the TASE/SWAN 2-D program (TASE, 1994), and, the HEC-RAS program (USACE, 2002) using the ice cover modeling utilities within the program.

Using the TASE/SWAN 2-D program, a conservative approach was developed whereby a static ice cover with complete blockage of the river channel to a bank full elevation along the length of the ice cover location was modeled.

Again, the quantitative data provided by (TSH, 1981c) provided a basis for describing the ice cover thickness over the reach of interest for modeling of ice cover using HEC-RAS. Default values provided by HEC-RAS for ice cover roughness were used. An average ice thickness of $0.5 \mathrm{~m}$ was used and the ice cover for each of the locations described in Figure 4.2 was assumed to be $100 \%$.

Based on this assessment, the highest computed water levels along the Cameco property boundary would result from the PMF. 


\subsubsection{Assessment of Flood Proofing Options}

Flood proofing can be defined as any combination of structural or nonstructural changes or adjustments incorporated in the design, construction, or alteration of individual structures or properties that will reduce flood damages. In other words, flood proofing includes any effort property owners may take to reduce flood damage to their property, individual structures and/or their contents (USACE, 1998).

The objectives of flood proofing are three-fold, namely, reducing flood damages, effectiveness and safety.

The U.S. Army Corps of Engineers (USACE, 1998) has developed a generalized flood proofing evaluation matrix which takes into account flood characteristics, site characteristics, and structure characteristics in the evaluation of particular flood proofing measures. The matrix, used for this evaluation, is presented in Table 4.3.

Based on the review of flood and site characteristics, wet and dry flood proofing options may not be effective alternatives for the Port Hope facility. Further, relocation of buildings and/or operations from Port Hope to another facility or to another location within the Port Hope facility outside of the flood inundation limits of the PMF is a potential flood proofing option but implementation may not be practical. The remaining alternatives, namely; elevating buildings (or lowest opening elevations) and constructing a flood containment structure (such as a levee or flood wall), are considered options for the Port Hope facility that can be effectively and practically implemented.

Figure 4.5 illustrates relevant profile information along the Turning Basin / Approach Channel to assist with better understanding of the requirements for flood proofing along this side of the property. Based on this illustration the following points are relevant.

- The Regional Flood water surface elevation is higher than the ground elevation near the water line along a large portion of the Cameco property, however, the flood rises above the roadway elevation in only a very limited area in the vicinity of some buildings.

- The PMF water surface elevation is above the ground elevation near the water line along all of the Cameco property, with minor exceptions.

- The lowest opening elevations of Cameco buildings along the Turning Basin / Approach Channel are higher than the PMF flood elevations with the exception of one building. 
Table 4.3 Generalized Flood Proofing Evaluation Matrix (adapted from USACE, 1998)

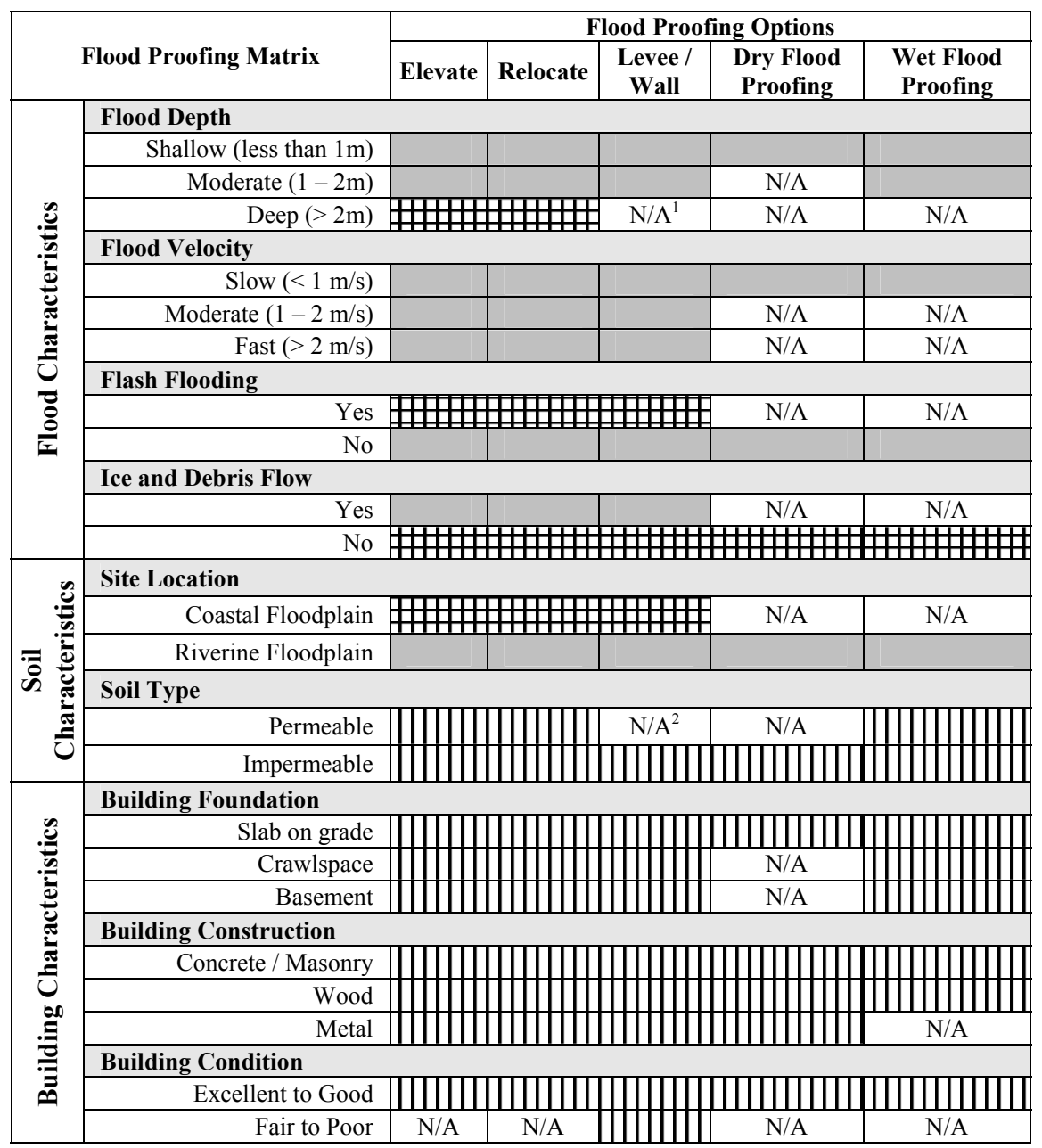

\section{NOTES:}

1. Space and aesthetics usually limit levee and floodwall heights for flood proofing to $2 \mathrm{~m}$. However, from an engineering viewpoint, greater heights are common.

2. Permeable soils allow seepage under floodwalls and levees; therefore, some type of cutoff feature would be needed beneath structures. Permeable soils also allow hydrostatic force to directly affect the structure; therefore, the walls and floor must be designed to resist hydrostatic force and buoyancy. 


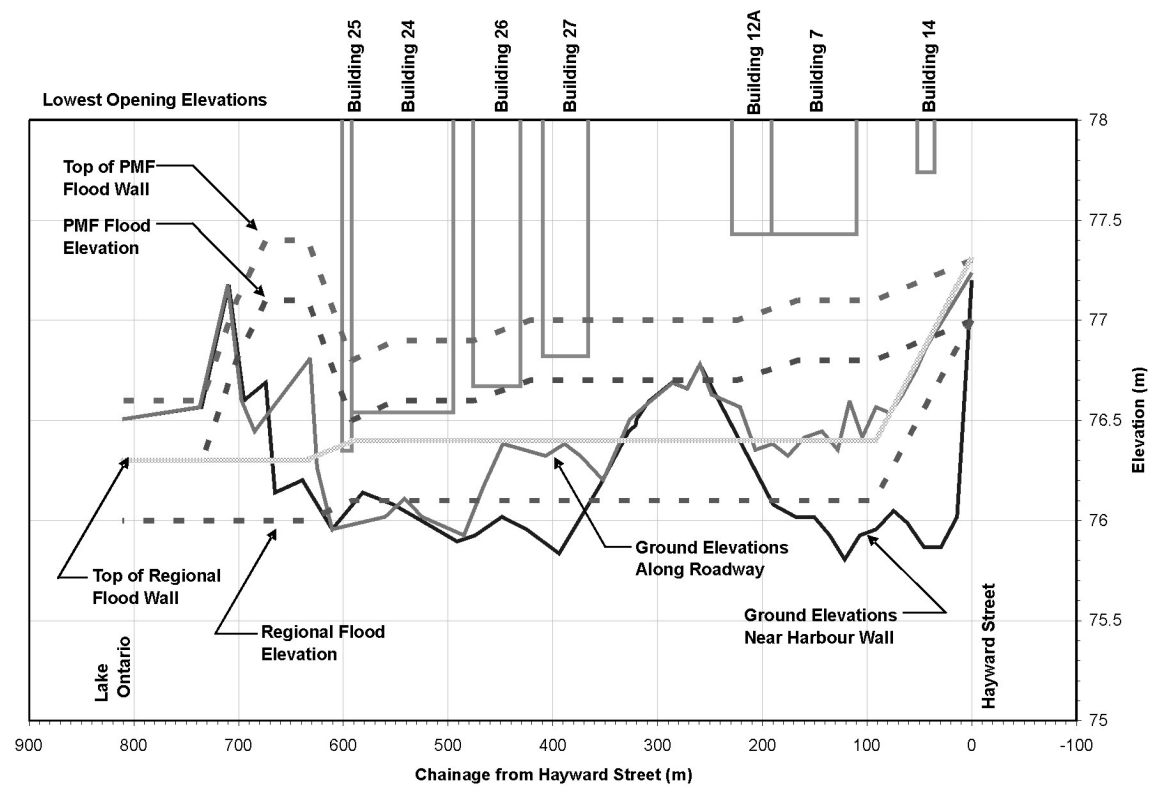

Figure 4.5 Profiles along the Turning Basin and Approach Channel.

A conceptual $700 \mathrm{~m} \pm$ flood berm along the Turning Basin / Approach Channel to protect the Cameco site from flooding from the Ganaraska River associated with the PMF (under existing conditions) was recommended. The flood berm also incorporates a conservative freeboard allowance of $0.3 \mathrm{~m}$.

Using the HEC-RAS model of the Regional Flood, the impact of the flood berm on computed water surface elevations within the study reach was evaluated. The results confirm that the implementation of the flood berm on the Cameco property does not change computed water levels for the Regional Flood within the study reach.

A number of internal storm drains discharge from the Cameco Port Hope facility to the Turning Basin / Approach Channel were also identified. These drains did not have flow controls installed at the discharge points. It was therefore recommended that Cameco evaluate the requirement for flow controls on these storm drains.

It was further recommended that Cameco undertake a review of the internal drainage system at the Port Hope facility to ensure that it can effectively function during a PMP/PMF. 


\section{References}

ADWR (2002).Floodplain Hydraulic Modeling, State Standard for Floodplain Hydraulic Modeling, Arizona Department of Water Resources Dam Safety Section, July 2002.

NBDOE (1989).New Brunswick River Ice Manual, The New Brunswick Subcommittee on River Ice, Environment Canada New Brunswick, August 1989.

OMNR (1988a).Flood Plain Management in Ontario Technical Guidelines, Ontario Ministry of Natural Resources, 1988.

OMNR (1988b).Flood Plain Planning Policy Implementation Guidelines, Ontario Ministry of Natural Resources, October 1988.

OMNR (2002).Technical Guide for River \& Stream Systems: Flooding Hazard Limit, Ontario Ministry of Natural Resources, 2002.

TASE (1994).TASE/SWAN Plus v3.0, User's Manual, TASE Software Inc., 1994.

TetraTech (2004). Review of the Draft Environmental Impact Statement for River Management Alternatives for the Rio Grande Canalization Project, United States Section International Boundary and Water Commission, Tetra Tech, ISG, 2004.

TSH (1981a).Ganaraska River Flood Control Study, Totten Sims Hubicki, 1981.

TSH (1981b).Calibration of HYMO Model, Totten Sims Hubicki, 1981

TSH (1981c).Ganaraska River Ice Data in the Town of Port Hope, Totten Sims Hubicki, 1981.

TSH (2004).Ganaraska River Regional Storm Floodline Review for the Reach Adjacent to the Cameco Corporation Property, Totten Sims Hubicki, June 2004.

USACE (1998).Flood Proofing Performance, Successes and Failures, US Army Corps of Engineers, October 1998

USACE (2002).HEC-RAS, River Analysis System v3.1, US Army Corps of Engineers, Hydrologic Engineering Centre, 2002. 